\title{
TURISTA EM TRANSE
}

\section{Arthur Vergueiro Vonk*}

\section{Resumo}

Trata-se de, a partir da leitura da série de crônicas $O$ turista aprendiz, escrita por Mário de Andrade durante viagem ao Nordeste em fins dos anos 1920, examinar os gestos de um intelectual às voltas com as contradições da experiência modernista brasileira. Através do exame de alguns textos decisivos, busca-se rastrear na composição literária a fixação dos impasses estéticos e históricos revelados no contato com o quadro social encontrado no curso da viagem.

\section{Palavras-chave}

Mário de Andrade, $O$ turista aprendiz, modernismo brasileiro, crônica literária, literatura e pobreza.

\begin{abstract}
The article presents a reading of $O$ turista aprendiz, the series of chronicles written by Mário de Andrade during his trip to the Brazilian Northeast in the late 1920's. The main interest is to describe the reactions of an intellectual haunted by the contradictions of the Brazilian modernist experience. Through the analysis of two relevant chronicles, the reading examines the esthetical and historical impasses revealed in the contact between the writer and the social configurations to which he was exposed during the trip.
\end{abstract}

\section{Keywords}

Mário de Andrade, O turista aprendiz, Brazilian modernism, literary chronicle, literature and poverty.

* Mestre em Teoria Literária e Literatura Comparada pela FFLCH-USP. Email: vonkarthur@gmail.com. 


\section{“À \\ s nove cortamos Jardim de Seridó, uma cidadinha de Tarsila, toda colorida limpa e reta". Assim o pequeno núcleo urbano, seu "ar} de progresso" em meio ao "deserto nordestino", ganha projeção nacional na descrição algo telegráfica estampada em um jornal paulista em fevereiro de 1929. A referência pictórica, timbrando o espírito modernista, a um tempo nos põe a par das coordenadas intelectuais do viajante e indicia o movimento encenado em sua prosa: há um desnível de base entre o repertório avançado e a "miséria medonha" da paisagem (ANDRADE, 1983, p.299-300). Em ato, a crônica de Mário de Andrade, escrita durante a viagem ao Nordeste, explicita os dois polos que balizarão a maneira pela qual o Turista Aprendiz fixará a sua relação com realidades até então inéditas no quadro do movimento lançado no Sudeste no início da década. Viagem dentro da viagem, o giro de automóvel, "fazendo quase que toda a volta do Rio Grande de Norte" (ANDRADE, 1983, p.285), reserva ao cronista do Diário Nacional contato com sintomas inequívocos daquilo que, décadas mais tarde, seria generalizadamente identificado no Brasil como subdesenvolvimento: a seca, a miséria, a exploração do trabalho levada aos limites (e além deles), famílias de retirantes, o descaso do governo. Não por acaso, as cinco crônicas, referentes aos dias entre 18 e 22 de janeiro de 1929, têm fecho drástico: último da pequena série, o texto que evoca Tarsila do Amaral passa pelo devaneio, tão acalorado quanto confuso, a respeito da possibilidade de "revolução no país", projeta um "cangaço secreto" e justiceiro e, por fim, emite o estampido da recusa a "fazer literatura diante desta monstruosidade de grandezas que é a seca sertaneja do Nordeste" (ANDRADE, 1983, p.300-301).

De tom mais amaneirado, a passagem que tematiza a região do Seridó não deixa de conter ao menos um componente do eixo de problemas em que se movem as reações de Mário de Andrade. Nela, a referência a uma composição de Tarsila ocorre precisamente quando se trata de enquadrar uma situação de exceção, a de uma "cidade pra inglês ver", "catita por demais", em contraste com a "paisagem quase que exclusivamente de pedra" do sertão (ANDRADE, 1983, p.299-300). Em meio à gravidade que irá disparar a revolta, o desafogo estético - "um dos momentos de cor mais lindos que já tive neste aprendizado pra turista" (ANDRADE, 1983, p.300) -, justamente por não ser suprimido, confere ao movimento da exposição um senso de relações no qual se deixa entrever a posição do cronista, esteta e jornalista, gozoso e indignado, turista mas aprendiz. O intelectual modernista não se esconde, antes pelo contrário, e é precisamente ao indicar as coordenadas entre as quais se move no contato com matérias sociais precisas e difíceis que, ao meu ver, garante o interesse dessa prosa composta no calor da hora, escrita quase bruta mas complexa à sua maneira. Pois o epíteto "cidadinha de Tarsila" não só acena para o lugar social do escritor, tornando explícito o arco de referências implicado em seus juízos e descrições, como é aproveitado como um material a mais da composição da crônica; assim, posto em

1 Não pude averiguar se, no original publicado no Diário Nacional em 22 de março de 1929, a enumeração de adjetivos de fato prescinde da vírgula. 
relação com a paisagem agreste, permite fazer render a clivagem drástica entre duas situações materiais, de modo que a distância é incorporada à reflexão sobre os sentidos que a alegre curiosidade modernista pode assumir na experiência radical da viagem a uma espécie de outro Brasil. O fato de que se trata, na verdade, de um mesmo país talvez confira atualidade e dramaticidade aos movimentos do texto.

A particularidade local envolve o viajante desde o incômodo atlântico do trajeto de ida, quando escreve que "esta lesma de vapor vai num atraso brasileiro que chega a irritar até a epiderme" (ANDRADE, 1983, p.214, grifo meu). Segundo Gilda de Mello e Souza, de fato, as viagens ao Norte e ao Nordeste, em 1927 e 1928-29, ao subverterem o costume do destino internacional próprio ao "recreio da burguesia" (SOUZA, 2005, p.57), têm o significado não apenas de confirmar o interesse pela especificidade nacional, mas também de um encontro com a matéria para a qual se voltava o projeto estético-ideológico de Mário, cujas realizações anteriores, como demonstra a melancolia do movimento final de Macunaíma, já problematizavam qualquer triunfalismo. Ocorre que a "adesão franca aos componentes recalcados de nossa civilização" (CANDIDO, 1973, p.122), de que trata Antonio Candido, encontrava nas viagens uma realização original e exemplar, que levava o intuito de redescobrir o país ao plano da vivência efetiva. A experiência, contudo, é contraditória: assim como a paisagem de pedra, pó e atraso faz estranhar uma cidade colorida e ordenada, relativizando, através da comparação, o "mundo sem tensões" (SOUZA, 2009, p.329) proposto por certas paisagens pau-brasil de Tarsila - assim também a disposição modernista a "amar com veemência o exótico descoberto no próprio país" (CANDIDO, 1973, p.121) é requalificada pelo contato com formações sociais pauperizadas ao extremo, o que torna mais difícil a adesão imediata e pode ter o efeito de jogar luz nova sobre os dois termos do problema.

De um lado, o Nordeste, que, cinco décadas mais tarde, Celso Furtado identificaria ainda como "a face do Brasil em que transparece com brutal nitidez o sofrimento de seu povo" (FURTADO, 1981, p.13), era incorporado ao conjunto renovado de preocupações que os intelectuais dos maiores centros econômicos e culturais iam formulando. Assim um dos "chefes de fila" (SOUZA, 2005, p.49) do modernismo paulista reconhecia cidadania literária e intelectual à região em que apareciam "sem disfarces as malformações maiores de nosso desenvolvimento" (FURTADO, 1981, p.13). De outro lado, o desrecalque localista promovido pelo próprio modernismo encontrava seus limites, quando o heroísmo dos primeiros tempos deparava um quadro de questões que o artista consequente não poderia simplesmente resolver através do engenho da composição literária. Em ponto pequeno, as crônicas da "viagem etnográfica" de Mário ao Nordeste encenam aspectos desse impasse. Da irritação epidérmica ao estado de crise quanto a escrever literatura a partir da pobreza, as suas consequências serão de ordens várias - e talvez seja sintomático que, em crônica pouco posterior ao retorno a São Paulo, publicada na série Táxi, o turista volte ao Diário Nacional opondo um senso de urgência à "casa de pensão" em que se teria convertido o

2 Assim o próprio Mário de Andrade se referia à experiência (Cf. ANDRADE, 1983). 


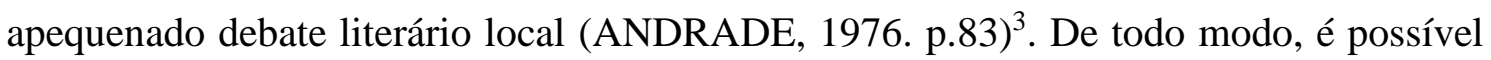
procurar na armação da prosa do Turista Aprendiz marcas do movimento que tentamos caracterizar - daí passarmos à leitura mais detida de duas crônicas da série, dois capítulos da lida do escritor com componentes recém descobertos de uma nacionalidade que a ida ao povo, a observação "carinhosa" do "homem-do-povo", revela problemática em mais de um sentido (ANDRADE, 1983, p.258).

Recife convidará o turista a enfrentar o desenvolvimento social contraditório sob uma manifestação diversa daquela a que nos referimos: a grande-angular voltada à seca sertaneja é substituída pelo corpo a corpo com uma espacialidade mais concentrada, mas não necessariamente menos monstruosa. É o que aponta crônica relativa ao dia 12 de dezembro de 1928, cuja abertura, todavia, dá-se sob o signo do mais desafogado passeio turístico, num flerte com o fantasioso que chega a lembrar o costume, frequente em Macunaíma, de oferecer explicações para a origem das coisas: "Vamos indo pela noite em busca da praia da Boa Vista, onde o coqueiro nasceu..." (ANDRADE, 1983, p.225). O passeio é de automóvel, mas, sem muito do traço futurista da passagem-relâmpago pela cidadinha de Tarsila - “cortamos Jardim Seridó", escreve Mário na crônica de 22 de janeiro do ano seguinte -, é desacelerado pela lentidão do veículo, que vai "tungão, lerdo, auxiliando as vistas da noite" (ANDRADE, 1983, p.225). A cor local traz peso e prepara o choque, que toma o restante do parágrafo de abertura e nos atira ao problema incontornável:

É zona de mocambo, e na água parada, encapuçada de mangue, as casinhas balançam feito luzes de canoas abicadas na praia. São luzes paradas da janelinha de frente, da porta de frente, luzes dum amarelento improvisado, que a água encomprida pra baixo, que nem fachos revirados. A imagem ficou ruim... Não são fachos não; é mas a água doente chupando tudo, chupando a vida da luz, chupando o sangue das gentes habitando aquilo, como quem se aboleta no socavão da morte... pra viver.

(ANDRADE, 1983, p.225)

Nada de Tarsila ou Pau-Brasil, portanto; antes, a revelação marca a ferro o texto, cujo tecido reproduz a dificuldade em apreender a cena de pobreza aguda. A própria escrita como que hesita: a descrição das habitações em área alagadiça é feita e refeita, três vezes ao todo. O símile inicial, que insinua a referência à normalidade de uma paisagem litorânea, é abandonado, como se a comparação com a neutralidade de canoas abicadas na praia pedisse especificação. Ela vem no período seguinte, o qual já contém a nota de precariedade ("luzes dum amarelento improvisado"), tornando a paleta de cores mais complexa, distante da ingenuidade de celofane, da "singeleza dos tons caipiras" que um crítico identificou nas telas de uma Tarsila do Amaral já antropofágica

3 "Os assuntos deste mundo são inumeráveis e os do Brasil tão urgentes e de importância tamanha..." (ANDRADE, 1976, p. 83). 
(NAVES, 1996, p.13). Assim como essa luminosidade, nem solar nem ingênua, o balanço das casinhas assume a feição mais drástica de "fachos revirados", mas a inversão tampouco dá conta de compor a imagem, que "ficou ruim...". Daí a terceira versão descartar o termo de comparação e aprontar a metáfora da água, parasita personificada, introduzindo a noção de doença. O percurso é curioso: a interrupção, se por um momento flerta com a constatação da impossibilidade de representar aquela matéria aguda, acaba por suprimir o distanciamento e investe com mais força na representação imagética, evitando o símile para estabelecer de vez a nota mórbida da cena. Veja-se que a guinada do período final do trecho tem o efeito de intensificar o páthos da descrição, através não só da radicalização assumida pelo léxico, como da dicção pontuada pela repetição do mesmo verbo três vezes em sequência. $\mathrm{O}$ emprego das orações coordenadas, ao mesmo tempo em que confere ritmo à enunciação, apoiada na plosiva bilabial da sílaba forte ("chupando"), garante um crescendo: as orações, cada vez mais longas ("chupando tudo, chupando a vida da luz, chupando o sangue das gentes habitando aquilo"), sugerem a aceleração da leitura e mesmo a urgência da causa. O arroubo, entre assombro e indignação, contém uma nota grandiloquente, preparando o contraponto com o refrão, que aparecerá outras duas vezes no texto, suspenso ao fim do parágrafo: "É triste, bem triste...".

Se não estivermos enganados, há uma afirmação da dificuldade, retesando a escrita e conferindo ao texto uma dimensão expressiva, a qual parece predominar em relação ao teor informativo que, em seu contexto imediato de veiculação, a notícia de miséria extrema não deixa de assumir. O caso é que os dados de representação custosa fazem com que o centro da cena seja ocupado pelo contato do escritor com essa matéria - à qual a forma não é indiferente. Assim, a própria exploração do reflexo da paisagem nas águas, recurso recorrente na obra de Mário de Andrade, tem aproveitamento particular. No diário da viagem à Amazônia, por exemplo, ao observar a orla quando da partida do Rio de Janeiro, o Turista Aprendiz se "deixa levar": a vista da cidade é "alucinante", desatando a imaginação do escritor, que não se faz de rogado e, ao explorar o clima de festa nas praias, compõe uma descrição também ela alucinada, na qual entram a Rainha de Sabá, a Dama das Camélias, Romeu e Julieta e milhares de cavalos numa "galopada imperial". Tudo disparado pela visão da água, que "geme oleosa, pesadíssima, refletindo devagar a iluminação assanhada das praias. Se sente festa nas praias (...)" (ANDRADE, 1983, p.54) ${ }^{4}$. Ainda que consideremos os contextos diversos de composição e publicação dos diários relativos às duas viagens, e lembremos os constrangimentos a que está sujeito o trabalho do cronista que compõe quase diariamente, será difícil imaginar que a água doente que circunda os mocambos recifenses pudesse desencadear uma série de associações desse teor. Mais que especular, todavia, cumpre observar o que de fato acontece à prosa de Mário ante a pobreza das habitações alagadiças.

Mesmo o impulso explicativo cede à encenação de uma prosa difícil, que faz

\footnotetext{
Aqui não se trata propriamente de uma crônica, mas de uma das entradas do diário que, a partir de suas notas de viagem, Mário foi compondo ao longo de mais de uma década. O título do manuscrito, que não chegou a ser publicado pelo escritor, é "O turista aprendiz: Viagens pelo Amazonas até o Peru, pelo Madeira até a Bolívia por Marajó até dizer chega" (ANDRADE, 1983).
} 
inflar o discurso e, novamente, trará à luz os esforços do escritor assombrado. O segundo parágrafo da crônica, mais longo, ensaia uma espécie de exposição interessada em entender a constituição da zona de mocambos a partir da migração da zona rural. $\mathrm{O}$ engodo da atração exercida pelo imaginário ligado à cidade grande é denunciado através da mescla entre a voz do escritor e projeções do pensamento dos sertanejos migrantes, sem, no entanto, atingir o nervo da questão: atendo-se ao fato da migração, a explicação não se pergunta propriamente pelo sistema de relações de produção que a qualifica ${ }^{5}$. Sem que o modo de organização da economia seja criticado até o limite, o esboço de uma análise social que, naquele contexto, dificilmente se completaria acaba por retomar uma série de imagens que engrossam a descrição inicial que comentávamos:

Foram se aboletando na barra da cidade, em casas que seriam pra dois meses e ficaram anos, de barro feio, cobertas com a própria folha caída dos coqueiros, brigando por causa dos terrenos com o rebento verde claro do mangue.

(ANDRADE, 1983, p.226)

A descrição reforça o juízo disfórico e, mais do que isso, antecipa uma posição: se o relato nordestino de Mário de algum modo (e claro que não isoladamente, mas em consonância com inquietações que já fermentavam naqueles anos vinte) precipita $o$ interesse pelos estudos brasileiros que se consolidaria com a sociologia dos anos seguintes, é significativo que o faça assumindo uma perspectiva divergente do principal intérprete nessa matéria. As linhas transcritas evidenciam, quase que ponto a ponto, a distância que separa Mário da visão da "pureza de habitação vegetal" (FREYRE, 1937, p.20) que a "livre fantasia" (CANDIDO, 1973, p.124) de Gilberto Freyre encontraria nessas "casas inteiramente à vontade entre as palmeiras e à beira do mar e da água doce" (FREYRE, 1937, p.20). Para o cronista, a "simplicidade" da "habitação caracteristicamente primitiva" não é "atraente" (FREYRE, 1937, p.20), tampouco a suposta "harmonização com o meio tropical" constitui uma "vantagem" (FREYRE, 1961, p.230) ${ }^{6}$. Pelo contrário, como se vê no texto do Turista, a precariedade da construção dos mocambos acusa provisoriedade, o aproveitamento dos recursos locais explicita a falta de meios; o material (barro) é "feio", e a proximidade com a natureza não é harmonia mas confronto ("brigando [...] com o rebento verde claro do mangue").

5 Cf. o comentário de Telê Porto Ancona Lopez a respeito da análise marioandradina das condições sociais nordestinas empreendida no Turista Aprendiz: "Nas crônicas focaliza principalmente as consequências no quadro social; não oferece as relações de produção capitalistas ou latifundiárias. Apresenta o dado econômico pesquisado e preciso, mas fica apenas no enfoque da miséria do 'proletário' (gosta do termo), não analisa seu papel na produção. Tenta fazer análise de fundo econômico, mas, na realidade, ilustra apenas sua identificação de cristão" (LOPEZ, 1972, p.52).

6 Para evitar a reposição de estereótipos, seria o caso apenas de lembrar que Freyre não ignora os "vícios do mucambo": reconhece, por exemplo, que as habitações podem ser "focos de infecção terríveis", o que, segundo seu raciocínio, seria devido "não à palha da construção, mas ao solo enlameado sobre o qual se levanta em geral a palhoça" (FREYRE, 1961, p. 230). A atenção a essa especificidade, se flerta com uma perspectiva mais atenta à lógica espacial própria à reprodução da força de trabalho no centro urbano, não desloca, todavia, a ênfase do argumento do sociólogo, ainda assim empenhado em descrever as "vantagens" do mocambo. Daí, a meu ver, permanecer a base do contraponto com a visão disfórica de Mário. 
Não equilíbrio (ou mesmo luxo) de antagonismos", mas "imundície de contrastes" (ANDRADE, 2002, p.16) ${ }^{8}$. O texto de Mário, em realidade, estrutura-se a partir de uma lógica binária e irresolvida, aproveitando em mais de um nível o senso de contrastes que resulta de seu diagnóstico dos mocambos do bairro da Boa Vista - que, para começo de conversa, revela ser o oposto daquilo que o adjetivo contido no toponímico prometia. A percepção da dualidade está na constatação da justaposição entre a região periférica e a cidade oficial: "[Os mocambos] Alastram o tamanho da cidade grande, formando na barra dela, um babado de barro e folhas secas" (ANDRADE, 1983, p.226). Se lembrarmos o parágrafo inicial da crônica, veremos que algo desse teor já se manifesta no paradoxo com que Mário conclui a primeira descrição das condições de habitação de quem "se aboleta no socavão da morte... pra viver". Indo adiante, a oposição será central também na comparação que mina de vez a perspectiva tradicional do turista ao equiparar o elemento típico, tido como um dos encantos da paisagem litorânea nordestina, com o volume de palhoças: "Hoje os mocambos são tão numerosos como os coqueiros" (ANDRADE, 1983, p.226). O campo aberto ao consumo conspícuo do lugar - central na constituição do fenômeno moderno do turismo (cf. ENZENSBERGER, 1985, pp. 205-225) - é inviabilizado; entre a fantasia dos coqueiros e o horror dos mocambos, vem à tona a visão dilacerada que faz do texto o seu espaço de cristalização, de modo que tudo nessa crônica de Mário parece indicar uma experiência, bastante palpável e imediata, da "dor dos irreconciliáveis" que, no caso da viagem à Amazônia, aparecia ligada à "infelicidade do acaso pela frente" própria aos dilemas de uma claudicante "constituição moral" na civilização sulamericana (ANDRADE, 1983, p.166). Se ali a reflexão cumpriria voo mais amplo, debatendo os problemas da formação cultural do país, no caso recifense o problema está à flor da pele; se lá era possível que Mário afirmasse que tal dor dos irreconciliáveis "não é de ser operário, (...) não é de ser intelectual, independe de classes e políticas" (ANDRADE, 1983, p.166) - dizendo respeito portanto à zona menos determinada da 'entidade nacional' -, o corpo a corpo com a geografia nordestina garantirá um tratamento diverso do problema. A miséria é da "gente do mangue" e também do intelectual": "Recife é mais sincera, conta a tristura de tantos desiludidos, com uma força que me queima agora o prazer de rolar pela Boa Vista, na fresca do ventarrão" (ANDRADE, 1983, p.226).

7 Para o estudo da centralidade da noção na obra de Freyre, ver ARAÚJO, 2005.

8 Uma espécie de fenomenologia da "sensação de dualidade que impregnaria a vida mental numa nação periférica" - no caso, a nossa - é feita por Paulo Eduardo Arantes (ARANTES, 1992, p. 14) ao estudar o Sentimento da dialética na experiência intelectual brasileira.

9 Uma lembrança: ao elaborar suas memórias político-sentimentais do Recife, com a mira sempre na revolução que poderia ter sido e que não foi, Francisco de Oliveira faz uma menção reveladora das continuidades perversas da combinação entre atraso e avanço que move nossa modernização. Ao descrever os meandros do bairro da Boa Vista, registra o que parece ser o futuro da zona de mocambos que impressionara Mário de Andrade: "entre alagados infames, ficava o Coque, o nec plus ultra da miséria recifense. Levei Celso Furtado para conhecê-lo, pois não existia no seu primeiro tempo de Recife, e o antitemperamental e weberiano quase vomitou" (OLIVEIRA, 2008, p.35). Veja-se que o páthos da pobreza extrema não só não é exclusividade do texto do Turista como marca presença na geração seguinte, travo indelével nas muitas voltas do parafuso que a intelectualidade brasileira descreve ao cumprir sua por vezes comovida obsessão - talvez inoperante nos dias de hoje - em (re)descobrir e transformar o país. 
Esse o fecho da crônica de 12 de dezembro, que cumpre o papel de assinalar a particularidade da pobreza recifense, mais à vista do que nos "cortiços invisíveis" de São Paulo e Rio de Janeiro. O período final repõe o andamento dual que vem marcando o discurso do cronista; também aqui, prazer e tristura formam um par de opostos que reafirma o sentimento de um objeto desconjuntado, assinalando, todavia, uma direção importante: o escritor se faz, ele mesmo, o palco de manifestação dos contrastes, cujo lugar passa a ser, por assim dizer, seu próprio corpo ${ }^{10}$. Refrescado pelo vento noturno, açoitado pelo calor da tristeza, o seu procedimento parece ser o de acolher em si o contraste que cinde o seu objeto. A sua implicação na cena é, portanto, total, de tal maneira que a estrutura binária que verificamos não é apenas externa, própria à lógica de produção espacial das clivagens sociais; não só ganha, na forma de paradoxos e oposições, centralidade na construção do discurso - mas atinge o próprio sujeito, cuja tendência inicial a gozar os sabores do passeio se converte em impulso a se oferecer como destino final das tristuras e desilusões produzidas pelo funcionamento, complexo e coletivo, da vida social.

Esclarece-se assim, imaginamos, a operação através da qual o reconhecimento da paisagem e dos dados sociais compõe com a encenação da postura do escritor. A sensibilidade para os contrastes atualiza aquele programa de Turista Aprendiz a que nos referimos de passagem, assim expresso na crônica de 01 de janeiro de 1929: "Está claro que uma das minhas observações mais carinhosas vai se dedicando ao homem-do-povo. Afinal a situação das chamadas classes inferiores é boa ou ruim?" (ANDRADE, 1983, p.258). Uma disposição ética, portanto, mas compósita: a pergunta fundamental que baliza o contato com os espaços nordestinos, de cuja observação o cronista procura deduzir as condições de vida e o tipo de sociabilidade local, evidencia que não só ele não é um analista objetivo como essa dimensão de pesquisa não é autônoma em relação às outras feições que a viagem e a postura do viajante assumem. É o que se vê na própria formulação, que também cheira a dualidade - entre análise e expressão, convivem a postura carinhosa, de ordem afetiva e íntima, e uma manifestação inicial daquilo que Antonio Candido nomeou como consciência aguda do subdesenvolvimento ${ }^{11}$.

A convivência estranha mostra-se em vários níveis da composição das crônicas: da recorrência de oposições entre imagens à conjunção de posturas e atitudes intelectuais a princípio distintas, organiza também a relação entre momentos da viagem pelo Nordeste. De estrutura afim ao relato da passagem pelos mocambos da Boa Vista, uma das crônicas de Natal revela-se o oposto simétrico do mal estar recifense, ostentando diferenças substantivas, a começar pela figuração tranquila que fará sujeito e paisagem se harmonizarem, preludiando a dualidade recorrente, mas desta vez bem resolvida: "Natal era o destino do meu descanso e estou descansando. Gosto de Natal

10 Ao estudar a estrutura paradoxal de Macunaíma, José Antonio Pasta lembra as circunstâncias de composição da obra, referidas por Mário de Andrade como uma espécie de transe. $\mathrm{O}$ caso subsidia uma compreensão mais geral dos procedimentos e atitudes do escritor, fixadas pelo crítico numa formulação próxima ao que se pode ver na crônica em causa. Pasta atenta para a "pressão violenta, gerada por exigências contraditórias e igualmente impositivas, que Mário de Andrade, como ninguém, chamava sobre si, assumia e deixava atuar (...)" (PASTA, 1993, p.31).

11 Ver "Literatura e subdesenvolvimento", em CANDIDO, 2003. 
demais" (ANDRADE, 1983, p.232). A tópica do turismo é retomada, bem como juízos anteriores a respeito de outras cidades nordestinas, tudo funcionando para permitir o elogio da capital rio-grandense-do-norte. Se Recife oferece praias extraordinárias, se Salvador transporta o viajante ao passado colonial, se o excesso de atrativos "bocado egoísticos" obrigam o turista à vivência de uma hybris intranquila, a ausência de exotismo fará de Natal portadora de um "encanto honesto". Mas também bifronte: é precisamente a combinação de modernização e passado que parece garantir o interesse de uma capital que, "ao mesmo tempo, tem ar de chacra, um descanso frutecente (...)" (ANDRADE, 1983, p.232). A conjugação é repetida algumas vezes: a Natal de Mário é uma "cidadinha clara, moderna, cheia de ruas conhecidas encostadas na sombra de árvores formidáveis". O "seu pitoresco" foge ao estereótipo, é

um encanto honesto, uma delícia familiar para nós, um ar de chacra que a torna tão brasileiramente humana e quotidiana como nenhuma outra capital brasileira, das que conheço.

(ANDRADE, 1983, p.232)

Imagem (quase miragem, diríamos) de uma modernização que chega a bom termo, a cidade parece assentada na convivência pacífica de opostos, a ponto de essas linhas de Mário lembrarem, ironicamente, a valorização, recessiva mas importante na obra de Gilberto Freyre, da simplicidade popular, do "sábio, simples e harmônico ponto de vista dos mocambos" (ARAÚJO, 2005, p.254) cuja influência, segundo Ricardo Benzaquen de Araújo, iria além das palhoças, servindo a uma caracterização compreensiva da sociabilidade das camadas pobres em geral ${ }^{12}$. Ao descrever as margens do rio Potenji, o cronista marioandradino registrará

armazéns e casas humildes, sem aquela presença forte de tristura dos mocambos recifenses. Casinhas de proletários pobres, não tirando a gente do bem estar. É possível se viver nelas.

(ANDRADE, 1983, p.232)

Sem pretender aferir a objetividade da descrição, há de se notar a variação de postura, ponte para a compreensão do princípio que organiza o funcionamento do texto e os caminhos do Turista Aprendiz. Sumariamos: a pobreza aqui não incomoda, as habitações proletárias merecem o mesmo diminutivo que classificara a "cidadinha clara, moderna", há "conforto praceano" em plena "city", as benfeitorias da modernização (telégrafo, bancos, Hotel Internacional, casas de comércio) estão ao alcance de alguns passos, "tudo ali mesmo", em escala humana e simpática, "na rua que a escadinha abriu no meio do arvoredo", sem "nenhuma nota de novo rico" (ANDRADE, 1983, p.232). O aparente abandono do dilaceramento que dava o tom na crônica de Recife possuirá,

12 Para o comentário à visão de Freyre a respeito de uma sociabilidade fraternal, cultivada pela tradição popular nas camadas médias e baixas do Recife, ver o capítulo 6 da obra de ARAÚJO, 2005. 
talvez, algum parentesco com a noção de um "progresso inocente" ${ }^{13}$ perseguida pela poesia dos anos 1920 de Oswald de Andrade. A unificar a descrição de Mário, no entanto, um dado que especifica o teor da nota: o traço familista, em que reside a delícia de Natal, parece ser a chave da operação que faz com que o enquadramento de uma capital moderna, como o cronista ressalta, não exclua o ar interiorano. É ele, com tudo o que mobiliza, o elemento que permite que o turista sinta-se em casa, como escreverá em carta ao amigo Câmara Cascudo - afetivamente transformado em Cascudinho - pouco após o retorno a São Paulo ${ }^{14}$. Afora as qualidades de bom anfitrião do folclorista, caberá perguntar pelo sentido dessa notação, pois a insistência na dimensão familiar da experiência natalense, se pode ser explicada, ao menos em parte, por um dado de ordem biográfica, externo ao texto, tem relevância central na composição da crônica. Nessa ambiência se inscreve a supressão do estranhamento cujas consequências permitiam ao viajante, por exemplo, cultivar a sensibilidade aos contrastes que horrorizam e conferem urgência à denúncia em Recife. Com a eliminação do distanciamento por meio da acomodação familiar ao espaço, o sujeito chegará a uma versão abrandada do estado de impassibilidade, da "vida de pura sensibilidade" (MORAES, 2001, p.346) ${ }^{15}$ que passara a habitar as fantasias de Mário a partir da visão de um seringueiro amazônico devorado pela maleita ${ }^{16}$. A familiaridade se radicaliza até uma integração plena entre turista e paisagem, ou entre o sujeito e seu objeto:

Eh! ventos, ventos de Natal, me atravessando como se eu fosse um véu. Sou véu. Não atravanco a paisagem, não tenho obrigação de ver coisas exóticas... Estou vivendo a vida de meu país...

(ANDRADE, 1983, p.233, grifo meu)

No ar, algo de uma utopia modernista - em 1925, ao comentar a poesia de Oswald, Mário apontava os limites da primeira empreitada de revisão do país, projetando seus desdobramentos: "Agora já estamos observando o Brasil e nos acomodando com ele tal como é. Só falta viver o Brasil. Os que vierem depois da gente poderão fazer isso" (ANDRADE, 2003, p. 83, grifo meu) ${ }^{17}$. A coincidência de formulações indicaria a realização do projeto, salto prodigioso sobre a própria sombra, alcançado no espaço de três anos, tornado possível pela mística do lugar agradável? Não

13 A expressão é de Roberto Schwarz, cuja análise da suspensão do antagonismo entre as "matérias colonial e burguesa" na poesia pau-brasil oferece um esquadro crítico que procuramos aproveitar, sem deixar de buscar as especificidades da movimentação, sem dúvida mais atormentada, de Mário de Andrade. Cf. “A carroça, o bonde e o poeta modernista”, em SCHWARZ, 1987, p. 24.

14 Projetando a posse de uma futura "maloca numa praia natalense", Mário imagina a convivência com o amigo a partir do resgate do sentido de sua vivência na cidade de Cascudo: "E fícaremos tempo, muito tempo revivendo nada de viagens nem de notícias, revivendo a nossa vida em comum - vida de família antiga brasileira que deixada em novembro passado aqui na rua Lopes Chaves, fui encontrar de novo, poucos dias depois na avenida Jundiaí, Vila Cascudo, Natal” (MORAES, 2010, p. 156). Grifo meu. A carta é de 06/03/1929.

15 A expressão é citada em SOUZA, 2005, p 59.

16 Ver ANDRADE, 1983, p. 107. Também as crônicas "Maleita I" e "Maleita II", em ANDRADE, 1976, pp. 453-459.

${ }^{17}$ Grifos meus. 
chegaríamos a afirmá-lo, até porque isso significaria isolar a crônica, abstraindo o caminho movimentado de que, como esperamos ter mostrado, é um momento. De toda forma, não deixa de intrigar o destino do complexo de problemas apontado na resenha marioandradina de Pau Brasil, que identificava as insuficiências dos atalhos oswaldianos e opunha à "pândega de superfície" a "alegria da sabença que descobre (...) [e] verifica" (ANDRADE, 2003, p. 83). Pois o labor do exame parece ele mesmo atalhado pela imagem com que Mário conclui a crônica de 16 de dezembro. Ela aponta uma espécie de superação mágica do travejamento, solução de lógica sui generis, segundo a qual a participação do intelectual nas coisas de seu tempo e lugar se daria pela supressão imediata de distinções. Suprime-se, por exemplo, o trabalho - é no "descanso" que o cronista poderá ser um com o lugar, sem "obrigações" (que remetem tanto ao automatismo das visitas turísticas como ao sentido militante da relação que Mário estabelecia com o país). Na esteira dessa suspensão, são apagados os traços de origem do escritor, inclusive os de classe, como sugere o aproveitamento da ambiguidade das formas pronominais ("Casinhas de proletários pobres, não tirando $a$ gente do bem estar. É possível se viver nelas"18).

No limite, seguindo a toada, o escritor deixaria de ser si mesmo, dissolvendo-se integralmente nas coisas e lugares de Natal. Sem que a derradeira metáfora do véu negue essa exacerbação, há em sua formalização um elemento que parece, no entanto, repor a presença inconfundível do Turista Aprendiz: a reiteração excessiva da integração à paisagem é própria de sua pena, e confere traço personalíssimo ao momento que seria de dissolução. A tranquilidade natalense, assim, sem ser propriamente negada, recebe, em seu ponto culminante, uma formulação marcada por excessos. Os quatro últimos períodos da crônica, reproduzidos acima, têm algo de superlativo, desde a repetição de vocábulos e a estruturação reiterativa até a concentração inquietante de consoantes fricativas - empenhadas, diríamos quase brincando, em concretizar algo tão imaterial como o vento... De fato, há vento por toda parte nessas poucas linhas, a ponto de a exploração da sonoridade esboçar uma tomada de cena, sobrepondo-se ao plano semântico. Estranha impassibilidade, portanto, essa que crava a presença do sujeito a cada nota, precisamente no momento em que ele trataria de registrar a própria conversão a um estado de indiferenciação com a paisagem. Se a leitura fizer sentido, o estilo da prosa, seu cultivo da desmedida, "dado essencial da linguagem marioandradina" (FRAGELLI, 2010, p.100), segundo um crítico, fornece uma determinação a mais aos movimentos protagonizados pelo intelectual em sua experiência de turista, nervo do problema que vínhamos acompanhando.

Seja para compreender à distância, seja para participar intimamente, o trânsito do cronista pela vida nordestina faz-se notar pelo esforço ostensivo, extremo de movimentação que não assenta e expõe em seu traçado tanto o sentimento das coisas locais como o fundo intelectual e as determinações de classe que o acompanham. Isso

${ }^{18}$ Grifos meus. 
mesmo quando estas aparentemente saem do esquadro. $\mathrm{Na}$ crônica de Recife, a clivagem social, levada ao limite, rebate-se paradoxalmente sobre a figura do escritor, fazendo dele o lugar de manifestação de todo o sofrimento, instância na qual se precipitam dramaticamente as contradições (e, com isso, desloca para o segundo plano a desigualdade objetiva). A apaziguada Natal é palco de operação análoga, na viabilização do retrato de uma cidade de tensões sublimadas através da fusão misteriosa entre o sujeito-escritor e sua matéria - no limite, seu país ${ }^{19}$. O percurso entre as duas posições, de estrutura similar apesar da grande diferença, parece corresponder ao motor do espetáculo produzido pela inquietude ao mesmo tempo curiosa e angustiada de Mário de Andrade. Quando o elemento de angústia sobressai (sem nunca ser propriamente separado da curiosidade), a figura do cronista parece atingir uma espécie de experiência-limite, que inclui a questão a respeito da viabilidade de o intelectual dar conta de uma matéria vertiginosa. Como se à beira de um abismo, ele flertará, em passagem que agora reproduzimos por extenso, com a constatação de uma impossibilidade radical de expressão:

(...) uma indigestão formidável de amarguras, de sensações desencontradas, de perplexidades, de ódios. Um ódio surdo... Quase uma vontade de chorar... Uma admiração que me irrita. Um coração penando de amor doloroso. Não estou fazendo literatura não. Eu tenho a coragem de confessar que gosto de literatura. Tenho feito e continuarei fazendo muita literatura. Aqui não. Repugna minha sinceridade de homem fazer literatura diante desta monstruosidade de grandezas que é a seca sertaneja do Nordeste. Que miséria e quanta gente sofrendo... É melhor parar... Meu coração está penando por demais...

(ANDRADE, 1983, p.301)

São linhas impressionantes. De alguma maneira, o trecho fixa, em grau máximo de concentração, traços de estilo que procuramos descrever: paradoxos, oxímoros, oposições, reiterações, tendências desmedidas, são chamados como que pelo nome, elevados ao plano da consciência, sem prejuízo da tonalidade quase desesperada. $\mathrm{O}$ reconhecimento de uma postura não garante o seu controle, o que fica claro se repararmos como o ritmo marcado pelos períodos curtos, com uso de construções nominais e reticências que suspendem a organização sintática do discurso, faz com que a tendência à autorreflexão seja ocupada pela disposição confessional. Por um lado, formula-se uma crítica, das mais incisivas de que tenho notícia nas letras brasileiras do período, à postura literária diante da vida arrasada. A radicalidade, por outro lado, é vazada em forma extremamente literária e, mais do que isso, tipicamente marioandradina. Assim como a imagem de um "amor doloroso", de uma "admiração

19 O vínculo entre os dois procedimentos parece ter relação com uma estrutura básica da obra de Mário de Andrade, que Fragelli designa como "a conversão ruinosa, negativa, de máxima desindividuação em extremo individualismo e vice-versa", a qual, ainda segundo o crítico, atualiza uma lógica sacrificial da qual o procedimento que identificamos não está distante (FRAGELLI, 2010, p.120). As observações que se seguem são em boa medida devedoras ao trabalho do autor, mas não podemos, neste momento, desenvolver as possíveis convergências entre o movimento descrito no Turista Aprendiz e os resultados de sua pesquisa. 
que irrita" ou de uma "monstruosidade de grandezas", o discurso realiza, a olhos vistos, uma espécie de pirueta, menos circense do que trágica (o que, no desenvolvimento da crônica moderna brasileira, é digno de nota). Sem que possamos tirar todas as consequências da operação, é possível reatar o argumento: a constatação de impossibilidade volta a trazer ao centro da cena a figura do intelectual-escritor, que ganha mais luz do que a própria pobreza.

No texto de Mário, algo de uma recusa a reproduzir a fachada vem à tona a partir de um material ao mesmo tempo arcaico e atual. Não há prazer ou figuração possível, mas essa impossibilidade é figurada. Ao procurar lidar com ela, vemos o cronista prestando testemunho das próprias dificuldades; a sua movimentação é sintoma, mas também conquista de uma composição que, como se mimetizasse os contrastes de que trata, não esconde a drasticidade dos gestos a que é obrigada. Consequente em seus torcicolos, a postura terá relação, talvez, com as condições da empreitada do turista, que mobilizara economias ${ }^{20}$ e ia como correspondente de um órgão do Partido Democrático, então sob o frescor de uma provisória primavera antioligárquica. Mário viajava também em alguma medida desgarrado da calorosa burguesia paulista, livre da companhia de Dona Olívia Guedes Penteado, dama do café que acompanhara à Amazônia. De todo modo, o disparate da viagem, o que ela tem de excepcional, é fixado nas piruetas que tentamos caracterizar. Afinal, o próprio país revelara-se, ele mesmo, mais e mais disparatado - mas não é simplesmente a sua figuração que acompanhamos, e sim a tentativa de apreendê-lo por um escritor meio turista, meio missionário. Mário de Andrade empenha-se em transpor os limites de uma experiência intelectual que, ao confrontar a própria base material, é flagrada em uma espécie de insuficiência - a certidão de modernista paulista parece se reapresentar quando o escritor, pretendendo-se liberto, oferece-se ao contato efetivo com a vertigem nordestina. Aí podemos descobri-lo um "emissário autodesignado do autoconhecimento nacional" (SCHWARZ, 1999, p.68), como escreveu Roberto Schwarz. Mas o choque rende e se deixa registrar na forma de "circunvoluções cerebrinas" 21 . Ainda que preso a sua classe e a algumas roupas (de linho branco, no caso), o cronista não mente à sua matéria, mesmo quando, como em Natal, parece procurar escapar dela. Essa uma das lições da prosa do Turista Aprendiz.

20 Em carta a Bandeira datada de 11 de julho de 1928, Mário se refere a texto a ser publicado em uma revista carioca, emendando, a respeito do responsável pelo veículo: "Além disso ele me paga os artigos e estou carecendo disso pra ver se ajunto algum arame pra ir pro Nordeste no fim do ano" (MORAES, 2001, p.396).

21 Tomo a expressão de estudo de Paulo Arantes, em que é empregada em contexto bastante diverso, na caracterização do gesto de certo tipo intelectual alemão de inícios do século XIX, às voltas com a "marginalidade social" e com a "existência malograda" em que o confinava o atraso material em relação aos países da vanguarda do desenvolvimento capitalista (ARANTES, 1996, p.221-223). 


\section{Referências bibliográficas}

ANDRADE, Mário de. Táxi e crônicas no Diário Nacional. Estabelecimento de texto, introdução e notas de Telê P. A. Lopez. São Paulo: Duas Cidades/ Secretaria da Cultura, Ciência e Tecnologia, 1976.

. O Turista Aprendiz. Org. Telê Porto Ancona Lopez. $2^{\mathrm{a}}$ ed. São Paulo: Duas Cidades, 1983.

. "Tristão de Ataíde". In: Aspectos da literatura brasileira. 6 ed. Belo Horizonte: Ed. Itatiaia, 2002, p.13-35.

. "Oswald de Andrade: Pau Brasil, Sans Pareil, Paris, 1925”. In:

ANDRADE, Oswald de. Pau Brasil. 2a ed. São Paulo: Globo, 2003, p.73-83.

ARANTES, Paulo Eduardo. Sentimento da dialética na experiência intelectual brasileira: dialética e dualidade segundo Antonio Candido e Roberto Schwarz. Rio de Janeiro: Paz e Terra, 1992.

. "Origens do espírito de contradição organizado". In:

Ressentimento da dialética: dialética e experiência intelectual em Hegel: antigos estudos sobre o ABC da miséria alemã. Rio de Janeiro: Paz e Terra, 1996, p.213-241.

ARAÚJO, Ricardo Benzaquen de. Guerra e paz: Casa-grande \& senzala e a obra de Gilberto Freyre nos anos 30. 2a ed. São Paulo: Ed. 34, 2005.

CANDIDO, Antonio. "Literatura e cultura de 1900 a 1945". In: Literatura e sociedade. $3^{a}$ ed. São Paulo: Cia. Editora Nacional, 1973, p.109-138.

"Literatura e subdesenvolvimento". In: A educação pela noite \& outros ensaios. $3^{\mathrm{a}}$ ed. São Paulo: Ática, 2003, p.140-162.

ENZENSBERGER, Hans Magnus. "Uma teoria do turismo". In: Com raiva e paciência. Trad. Lya Luft. Rio de Janeiro: Paz e Terra/ Instituto Goethe, p.205225.

FRAGELLI, Pedro Coelho. A paixão segundo Mário de Andrade. Tese de doutoramento. FLCH-USP, 2010.

FREYRE, Gilberto. Mucambos do Nordeste. Rio de Janeiro: Ministério da Educação e Saúde, 1937.

Sobrados e mucambos: Decadência do patriarcado rural e desenvolvimento do urbano. $3^{\mathrm{a}}$ ed. $1^{\mathrm{o}}$ tomo. Rio de Janeiro: Livraria José Olympio Ed., 1961.

FURTADO, Celso. "Uma política de desenvolvimento para o Nordeste". In: Novos estudos, n. 1, dezembro de 1981, p.12-19.

LOPEZ, Telê Porto Ancona. Mário de Andrade: ramais e caminho. São Paulo: Duas Cidades, 1972. 
MORAES, Marcos Antonio de (org.). Correspondência Mário de Andrade \& Manuel Bandeira. $2^{\text {a }}$ ed. São Paulo: IEB/Edusp, 2001.

Câmara Cascudo e Mário de Andrade: cartas 1924-1944. São Paulo: Global, 2010.

NAVES, Rodrigo. A forma difícil: ensaios sobre arte brasileira. São Paulo: Ática, 1996.

OLIVEIRA, Francisco de Oliveira. A noiva da revolução/ Elegia para uma re(li)gião. São Paulo: Boitempo, 2008.

PASTA, José Antonio. “Tristes estrelas da Ursa: Macunaíma”. Cadernos Porto \& Vírgula, no 4. Porto Alegre: Secretaria Municipal da Cultura, 1993, p.27-32.

SCHWARZ, Roberto. "A carroça, o bonde e o poeta modernista”. In: Que horas são? São Paulo: Companhia das Letras, 1987, p.11-28. " "Discutindo com Alfredo Bosi". In: Sequências brasileiras. São Paulo: Companhia das Letras, 1999, p.61-85.

SOUZA, Gilda de Mello e. "O mestre de Apipucos e o turista aprendiz". In: A ideia e o figurado. São Paulo: Duas Cidades; Ed. 34, 2005, p.49-70. . "Vanguarda e nacionalismo na década de vinte". In: Exercícios de leitura. $2^{a}$ ed. São Paulo: Duas Cidades/ Ed. 34, 2009, p.305-344. 